\title{
Are face masks useful for limiting the spread of COVID-19?
}

Hong Kong Med J 2020;26:267-8

https://doi.org/10.12809/hkmj208566

To the Editor-Coronavirus disease 2019 (COVID19) is primarily spread through respiratory droplets or close contact. ${ }^{1}$ Healthcare workers are advised to wear surgical masks and other personal protective equipment to prevent the spread of COVID-19. The World Health Organization recommends that the public need to wear a mask only when caring for a person with suspected COVID- $19,{ }^{2}$ and emphasises frequent handwashing and social distancing (avoiding close contact within 1 to $2 \mathrm{~m}$ ) in order to save the limited supply of available masks for carers and healthcare workers who rely on them. ${ }^{3}$ Further to these recommendations, some Asian countries such as China, Japan, South Korea and Thailand, and also Hong Kong, face masks are also recommended in crowded places or on public transport. Although there is limited evidence that face masks are effective in protecting the wearer from infection, wearing face masks can prevent transmission from an infected person, including those who may be asymptomatic or presymptomatic. ${ }^{4}$

Recently, researchers from The University of Hong Kong have found the ability of surgical masks to reduce seasonal coronavirus in respiratory droplets and aerosols. ${ }^{5}$

Some international studies have also demonstrated the efficacy of surgical masks in preventing respiratory virus transmission. For example, in 2008, a randomised, controlled clinical trial study from Australia showed that surgical masks had efficacious protective efficacy of over $80 \%$ against the transmission of respiratory viruses. ${ }^{6}$ In 2011, Jefferson et $\mathrm{al}^{7}$ found that wearing a mask or N95 respirator might reduce respiratory virus infection. More recently, researchers from South Korea studied four patients infected with COVID19 and found that surgical masks helped prevent the spread of severe acute respiratory syndrome coronavirus 2 and reduced the viral load of a cough. ${ }^{8}$

On 3 April, the Centers for Disease Control and Prevention of the United States suggested wearing cloth face-coverings in a public area, in addition to social distancing, to prevent transmission in the community. ${ }^{9}$

Face mask wearing can prevent transmission of COVID-19 in the general population by limiting the spread from infected individuals, including those who are asymptomatic or pre-symptomatic.

\section{Author contributions}

All authors contributed to the concept of the study, acquisition and analysis of the data, drafting of the manuscript, and critical revision of the manuscript for important intellectual content. All authors had full access to the data, contributed to the study, approved the final version for publication, and take responsibility for its accuracy and integrity.

\section{Conflicts of interest}

The authors have no conflicts of interest to disclose.

\section{Funding/support}

The authors received no funding source/grants or other materials support for this work.

\section{${ }_{1,2,3}$ SK Law, PhD}

${ }^{4}$ Albert WN Leung, $\mathrm{PhD}$

${ }^{1} \mathrm{C} \mathrm{Xu}$ *, PhD

Key Laboratory of Molecular Target and Clinical Pharmacology, State Key Laboratory of Respiratory Disease, School of Pharmaceutical Sciences \& Fifth Affiliated Hospital, Guangzhou Medical University, Guangzhou, China

2 School of Chinese Medicine, Faculty of Medicine, The Chinese University of Hong Kong, Hong Kong

${ }^{3}$ Department of Science, School of Science and Technology, The Open University of Hong Kong, Hong Kong

${ }^{4}$ Asia-Pacific Institute of Aging Studies, Lingnan University, Hong Kong

*Corresponding author: xcshan@163.com

\section{References}

1. Modes of transmission of virus causing COVID-19: implications for IPC precaution recommendations. 29 March 2020. Available from: https://www.who.int/ publications/i/item/modes-of-transmission-of-viruscausing-covid-19-implications-for-ipc-precautionrecommendations. Accessed 16 Apr 2020.

2. Coronavirus disease (COVID-19) advice for the public: when and how to use masks. 17 March 2020. Available from: https://www.who.int/emergencies/diseases/novelcoronavirus-2019/advice-for-public/when-and-how-touse-masks. Accessed 16 Apr 2020.

3. To mask or not to mask: WHO makes U-turn while US, Singapore abandon pandemic advice and tell citizens to start wearing masks. 4 April 2020. Available from: https:// www.scmp.com/news/hong-kong/health-environment/ article/3078437/mask-or-not-mask-who-makes-u-turnwhile-us. Accessed 16 Apr 2020.

4. Feng S, Shen C, Xia N, Song W, Fan M, Cowling BJ. Rational use of face masks in the COVID-19 pandemic. Lancet Respir Med 2020 Mar 20. Epub ahead of print.

5. Leung NH, Chu DK, Shiu EY, et al. Respiratory virus shedding in exhaled breath and efficacy of face masks. Nat Med 2020 Apr 3. Epub ahead of print.

6. Maclntyre CR, Dwyer D, Seale $H$, et al. The first randomized, controlled clinical trial of mask use in households to prevent respiratory virus transmission. Int 
J Infect Dis 2008;12(Suppl 1):E328.

7. Jefferson T, Del Mar CB, Dooley L, et al. Physical interventions to interrupt or reduce the spread of respiratory viruses. Cochrane Database Syst Rev 2011;(7):CD006207.

8. Bae S, Kim MC, Kim JY, et al. Effectiveness of surgical and cotton masks in blocking SARS-CoV-2: A controlled comparison in 4 Patients. Ann Int Med 2020 Apr 6. Epub ahead of print.

9. Recommendation regarding the use of cloth face coverings, especially in areas of significant community-based transmission. 3 April 2020. Available from: https://www. cdc.gov/coronavirus/2019-ncov/prevent-getting-sick/ cloth-face-cover.html. Accessed 16 Apr 2020. 